\title{
Zasidranost pregovorov v besedišču govorcev slovenskega jezika
}

\author{
AlJA LiPAVIC OŠTIR \\ ANJA VASILJEVIČ \\ Mihaela KoletniK \\ Univerza v Mariboru, Koroška cesta 160, SI- 2000 Maribor, \\ alja.lipavic@um.si; anja.vasiljevic@gmail.com; mihaela.koletnik@um.si
}

SCN VII/1 [2014], 48-72

Prispevek prikazuje rezultate anket o poznavanju in rabi slovenskih pregovorov pri skupini informantov različne starosti v Sloveniji. Pregovori so del njihovega pasivnega leksikona (povprečno poznavanje v $83 \%$ in raba v $24 \%$ pri govorjenju ter $12 \%$ pri pisanju). Razlike kažejo tudi sociodemografski parametri, tako poznavanje pregovorov linearno narašča z izobrazbo informantov. Parameter kraj bivanja ni pokazal statistično pomenljivih razlik, enako velja tudi za parameter spol. Anketa je pokazala nekaj razlik tudi med posameznimi narečnimi skupinami. Nekatera odstopanja bi lahko pojasnile le nadaljnje raziskave, ki bi gotovo odprle tudi nova vprašanja in nakazale nove poti raziskovanja.

The statistical analysis of the results obtained by means of a survey conducted among speakers of the Slovene language have shown that proverbs represent a significant part of the individual passive lexicons of the majority of speakers. The results have shown that the informants use proverbs verbally more often than in written form. The empirical study has a sociolinguistic character: a linear increase in proverb knowledge was ascertained based on the respective levels of education of the informants. The results have not revealed any significant differences with regard to the factors of location (living in a metropolitan or a rural area) and gender respectively, while individual differences were observed with regard to the factor of dialect. In order to explain some discrepancies, further research is needed, which surely would lead to new points of perspective on the matter.

Ključne besede: pregovori, jezikovna raba, sociolingvistika, izobrazba, starost, spol, narečja

Key words: proverbs, language use, sociolinguistics, education, age, gender, dialects 


\section{Uvod}

Prispevek predstavlja rezultate raziskave poznavanja in rabe pregovorov na območju štajerske, panonske in koroške narečne skupine. ${ }^{1}$ Pregovori so bili pridobljeni z anketiranjem različno starih informantov. Osnovo ankete so predstavljali nabor 67 pregovorov in sociodemografski podatki o informantih. Cilj raziskave je bil ugotoviti poznavanje in rabo pregovorov v povezavi s krajem bivanja, izobrazbo, spolom in narečjem informantov. V prispevku je prikazan tudi kratek prerez stanja sociolingvističnih raziskav na področju raziskovanja pregovorov v evropskem prostoru.

\section{Raziskave rabe in poznavanja pregovorov}

Na področju slovenistike pogrešamo obširne raziskave, ki bi obravnavale poznavanje in rabo pregovorov ${ }^{2} \mathrm{z}$ upoštevanjem sociolingvističnih parametrov. ${ }^{3}$ Več podatkov lahko črpamo iz raziskav iz drugih jezikovnih okolij. V nadaljevanju bodo na kratko predstavljene. Novejše razprave o pregovorih ugotavljajo (npr. Norrick 2007: 386), da se ti redko pojavljajo, da so hitro prepoznavni, ker $\mathrm{v}$ sobesedilu izstopajo, da stojijo $\mathrm{v}$ ospredju in da si jih zlahka zapomnimo. Navajanje pregovora pomeni tudi poznavanje tradicije in modrosti jezikovne in kulturne skupnosti, v kateri živimo. Paremiologija je že od svojih začetkov upoštevala geojezikovne dejavnike (Piirainen 2006: 196), vendar so raziskave s tega področja ostajale na področju etnologije in kulturologije. V zadnjih letih je nastalo nekaj raziskav s področja narečne frazeologije (pregled najdemo pri Piirainen 2006: 198), ki se osredinjajo na norme frazemov, na njihovo oblikoslovno, skladenjsko in leksikalno spremenljivost ter na razmerje do knjižne norme. Sociolingvistične raziskave na področju frazeologije so relativno nove, in to ne glede na ciljni jezik ali kulturno okolje. Sociolingvistika razume pregovore kot neke vrsto anomalijo (prim. Abrahams 1972: 64), saj so v svoji prvotni rabi v prvi vrsti stilizirano komunikacijsko sredstvo, ki se uporablja, da bi diskurz prenesli s področja osebnega na neosebno, iz sedanjosti v preteklost, od neformalnega koda do formalnega in retoričnega itd. Pregovori so

\footnotetext{
${ }^{1}$ Nekateri osnovni podatki o poznavanju in rabi pregovorov pri vseh govorcih in nekateri osnovni podatki o povezavi s parametroma spol in starost so predstavljeni tudi v Lipavic Oštir (2013).

2 Pregovore razumemo kot frazeme $\mathrm{z}$ lastnostmi stavkov; od stalnih frazemov se razlikujejo po tem, da v besedilno okolje niso vključeni z besediloslovnimi elementi, so splošne izjave ali sodbe, ki pojasnjujejo neko situacijo ali pa o njej sodijo, se vanjo umeščajo (Burger idr. 1982: 39). Zaradi svoje metaforike nam ponujajo izjave o stereotipih in kulturnih metaforah (Norrick 2007: 381), zaradi česar so primerni za psihololigvistične in tudi za medkulturne raziskave.

${ }^{3}$ Obširnejši pregled raziskav v evropskem prostoru je vključen v članek, ki obravnava rezultate anketiranja o poznavanju in rabi nemških pregovorov v Avstriji (Lipavic Oštir, Štavbar 2013).
} 
tudi formalne in retorične enote, ki se uporabljajo v celi vrsti formalnih in sociolingvističnih sobesedil. Abrahams (1972: 61) ugotavlja, da pregovorov v današnjem jeziku skorajda ne uporabljamo, vendar pa govorci poznajo njihove pomene in imajo celo predstavo o tem, kako učinkoviti so bili v preteklosti in katere funkcije so imeli. Od kod govorci poznajo pomene pregovorov, če ti ne spadajo v aktivni del našega besedišča? Abrahams (1972: 61) našteva naslednje vire: besedila, reklame, pesmi, leposlovje, opisi idr. Spoznamo jih tudi preko staršev, starih staršev, sorodnikov, učiteljev, iz literature in medijev, npr. pri poročanju športnih novinarjev, slišimo jih v cerkvi.

Podatke o poznavanju in rabi pregovorov nam ponujajo tudi raziskave iz nemškega govornega prostora, pri čemer se jih večina osredinja na frazeme 4 in manj na pregovore. Regionalni vidik v povezavi s pregovori obravnava Durčo (2005: 46-59), ki ugotavlja, da informanti na neki način poznajo okrog $95 \%$ pregovorov iz ankete, obenem pa se s starostjo povečuje poznavanje pregovorov in komplementarno niža pasivno obvladovanje. Splošen leksikografski leksikon se s starostjo ne spreminja, prihaja pa do kvalitativnega preoblikovanja razmerja aktivno - pasivno znanje, in sicer tako, da se s starostjo povečuje aktivna raba pregovorov. V raziskavi o poznavanju nemških pregovorov Grzybek (1991) določa minimum pregovorov, in sicer na osnovi 275 pregovorov in z anketiranjem 125 informantov v Severnem Porenju - Vestfaliji, pri čemer upošteva tudi vpliv spola, starosti, izobrazbe in kraja bivanja (mesto - dežela). Razmerje med mestom in podeželjem je veliko premalo raziskano (Burger idr. 1982: 134ff), ugotavlja se v glavnem samo, da se je raba pregovorov v podeželskem okolju zaradi vpliva številnih socialno-ekonomskih dejavnikov spremenila. Tradicionalne funkcije pregovorov so konzervativne, pregovore razumemo kot dejavnike, ki ohranjajo sistem in norme, torej so sredstvo za utrjevanje preživetih vrednot. Pogosto je poudarjena njihova vloga v (jezikovni) vzgoji in zavestno jih uporabljamo v določenih sobesedilih, imajo pa tudi avtoritativno težo. Analize kažejo (Burger idr. 1982: 136ff), da mladi namesto tradicionalnih pregovorov uporabljajo druge oblike frazemov in da je zaznati spremembe funkcije pregovorov, če se ti sploh še uporabljajo. Njihova primarna vloga ni več sklicevanje na avtoriteto, ampak imajo vlogo retoričnih, pogosto humornih sredstev v diskurzu in čustveni razpravi s sogovornikom.

Raziskave slovenskih pregovorov so večinoma paremiološke, npr. Grafenauer (1952), Rode (1989) in Stanonik (2000). ${ }^{5}$ Tovrstne raziskave so pozitivistične in v večji meri simptomatične kot sistematične. Grzybek (2008: 24-25) v svoji

\footnotetext{
${ }^{4}$ Prim. tudi naslednje raziskave: Häcki, Buhofer, Burger (1994) o poznavanju, rabi in presojanju 63 frazemov pri informantih s poklicnih šol, z gimnazij in s tehničnih šol (z upoštevanjem vpliva starosti, izobrazbe in spola), Ďurčo (1994) o vplivu starosti na poznavanje frazemov, Piirainen (2006) o ugotavljanju lokalnega vidika in poznavanja frazemov z upoštevanjem dejavnika starosti informantov in njihove mobilnosti, Filatkina (2005) o starosti, spolu, izobrazbi in kraju bivanja v luksemburški nemščini, Földes (1992) o regionalnem vidiku poznavanja frazemov v Avstriji.

${ }^{5}$ Prim. Grzybek (2008: 23).
} 
raziskavi skicira zgodovino slovenske paremiografije, ki jo začenja z Janezom Miheličem (1780), katerega zbirka pregovorov ni ohranjena. Sicer pa velja za prvo zbirko slovenskih pregovorov Megiserjeva iz leta 1592 (Paremiologia), ki ji je bilo pogosto očitano, da vsebuje hrvaške pregovore. Danes menimo, da gre za pregovore, skupne slovenskemu jeziku in kajkavski hrvaščini.

Dvom o Megiserjevi zbirki je morda posledica stališča, da je prva zbirka slovenskih pregovorov zbirka 150 pregovorov Ožbalta Gutsmanna iz leta 1777. V naslednjih sto letih najdemo nekaj manjših zbirk, prva obširnejša je Kocbekova iz leta 1887 (Pregovori, prilike in reki), ki jo Grzybek ocenjuje kot temelj slovenske paremiografije. Zbirka je bila kasneje (1934) razširjena in je predstavljala osnovo za naslednje zbirke (Bojc 1974; Prek 1970). Drugačen je pristop etnologinje Marije Makarovič (1975), ki paremiografske podatke dopolnjuje z raziskovanjem poznavanja pregovorov. Te je zbrala v 32 krajih po Sloveniji, pri čemer je v Ljubljani in Mariboru sodelovalo več informantov, vendar zbiranje žal ni potekalo sistematično po narečnih skupinah. Informanti so prepoznavali pregovore iz zbirke in zbirko dopolnjevali s pregovori, ki jih ta ni vsebovala. Ob tem so navedli še spol, starost in poklic. Marija Makarovič piše (1975: 207), da so za ugotavljanje resničnega stanja današnje rabe pregovorov zanesljivejša klinična opažanja, ki bi jih najlaže opravil etnolog - domačin. Sama se je odločila za ugotavljanje krajevne razširjenosti, saj razen v krajših zapisih, kjer so navedeni tudi kraji oz. območja zbiranja, pregovori tudi v dveh večjih zbirkah slovenskih pregovorov niso krajevno opredeljeni.

S pregovori se ne ukvarja samo jezikoslovje, ampak tudi druge vede, npr. narodopisje, ki svoje raziskave (paremiološke) umešča med jezikoslovje in slovstveno folkloristiko. Sámo zbiranje in zapisovanje pregovorov poznamo npr. v slovenskem prostoru že od 17. stoletja (Babič 2011: 27), medtem ko se je zanimanje za preučevanje pregovorov začelo $v$ tridesetih letih 20. stoletja. Paremiologija je v tem prostoru razumljena predvsem jezikoslovno in se tako osredinja na dialektološke, poetološke, deloma kognitivnolingvistične in jezikovnozgodovinske raziskave. Saša Babič (2011: 28) poudarja pomen jezikoslovnega znanja pri raziskavah pregovorov in vlogo dialektologije, ki je neobhodna pri razvozlavanju metaforičnosti pregovorov. Ob tem poudarja pomembnost zbiranja gradiva v sami rabi pregovora, predvsem v vsakdanji komunikaciji.

\section{Poznavanje in raba pregovorov pri različnih skupinah informantov}

Raziskava poznavanja in rabe izbranih pregovorov v vzhodnih slovenskih narečjih (2012) je bila opravljena s ciljem ugotoviti današnje poznavanje in rabo pregovorov. Opravljena je bila s pomočjo anketiranja informantov, glede nabora pregovorov in strukture ankete se naslanja na raziskavo rabe nemških pregovorov pri mladostnikih v Avstriji (gl. Lipavic Oštir, Štavbar 2013). Ker ob oblikovanju ankete še nismo razpolagali z novejšimi raziskavami poznavanja in rabe slovenskih pregovorov, ki bi izpostavljale področje pogostnosti, smo problem izbora pregovorov rešili tako, da smo izhajali iz pregovorov v podat- 
kovni zbirki SprichWort. Izbrali smo 76 nemških pregovorov, ki se najpogosteje uporabljajo v korpusu DeReKo in ki smo jih uporabili v anketi v Avstriji. Ker podatkovna banka SprichWort zajema tudi slovenske različice pregovorov, ki so preverjene v besedilnih korpusih slovenskega jezika, smo slovenske različice izbranih 76 nemških pregovorov pregledali in vključili le tiste, ki jih slovenski del podatkovne zbirke SprichWort navaja. Tako se je izbor skrčil na 67 pregovorov, ki smo jih preverili tudi v slovenskem korpusu Nova beseda.

V času anketiranja in obdelave podatkov se je v Sloveniji izvajala še raziskava na temo paremiološkega minimuma petdesetih najbolje poznanih pregovorov (Ďrčo, Meterc 2013). Avtorja vseh petdeset pregovorov razporejata v lestvici (2013: 23), in primerjava $\mathrm{z}$ naborom pregovorov, ki je bil uporabljen $\mathrm{v}$ naši anketi, pokaže naslednje. Prekrivanje ankete in paremiološkega minimuma je samo pri 11 pregovorih (Kdor išče, ta najde; Denar je sveta vladar; Jabolko ne pade daleč od drevesa; Kdor čaka, dočaka; Rana ura - zlata ura; Vaja dela mojstra; Bolje pozneje kot nikoli; Kdor prvi prid, prvi melje; Konec dober, vse dobro; Kdor visoko leta, nizko pade; Hiti počasi). Pregovor Kdor išče, ta najde je uvrščen na vrh lestvice, ostali so razporejeni po celotni skali. Razlog za neujemanje je nedvomno v različnih korpusnih izhodiščih obeh raziskav.

Anketa je bila izvedena med govorci slovenščine v severovzhodni Sloveniji. Informanti so bili izbrani glede na kraj bivanja, pri čemer so ob kraju bivanja navedli tudi kraj, v katerem so najdlje živeli - po tem smo jih tudi razdelili na govorce posameznih narečij. Informanti so navedli tudi spol, starost in stopnjo izobrazbe. Jezikovni del ankete obsega označevanje določenih vrednosti za vsak pregovor posebej. Tako so informanti označili, ali posamezen pregovor poznajo in ali vedo, kaj pomeni, nato so ocenili, kako pogosto ga uporabljajo pri govorjenju in pisanju. Ankete smo informantom izročali v tiskani obliki, izpolnjene so vsi z nekaj redkimi izjemami vrnili, tako da je skupno število anket 189. Rezultati ankete so bili statistično obdelani s programom SPSS. ${ }^{6}$

Struktura ankete glede na kategorije vprašanj je dvodelna. V prvem delu sta vprašanji, ki se nanašata na poznavanje posameznega pregovora (Pregovor poznam in Vem, kaj pregovor pomeni. Možni odgovori so: DA/NE/NE VEM), $\mathrm{v}$ drugem delu pa so informanti ocenjeveli rabo posameznega pregovora (Pregovor uporabljam pri govorjenju in Pregovor uporabljam pri pisanju). Možni odgovori so izbor števila na lestvici 1-5, pri čemer 1 pomeni pregovora nikoli ne uporabljam, 3 pregovor uporabljam včasih in 5 pregovor uporabljam zelo pogosto.

\footnotetext{
${ }^{6}$ Rezultati ankete so bili obdelani tako, da so bili v program vneseni po parametrih, in sicer vsaka vrednost posebej. Nato so bili statistično obdelani, pri čemer so bile določane povprečne vrednosti in ugotovljeni tisti pregovori, ki po vrednostih odstopajo od povprečja.
} 


\subsection{Poznavanje in raba slovenskih pregovorov}

Informanti so označevali poznavanje in rabo posameznega pregovora, da pa bi prikazali celotno sliko poznavanja in rabe pregovorov. V tabeli 1 prikazujemo povprečne vrednosti za vse pregovore, ki predstavljajo povprečne vrednosti za vsak posamezni pregovor $\mathrm{v}$ primeru vprašanj $\mathrm{A}$ in $\mathrm{B}, \mathrm{v}$ primeru ocenjevanja rabe $(\mathrm{C}, \mathrm{D})$ pa prikazujemo povprečne vrednosti za vse pregovore, ki predstavljajo povprečje vrednosti za vsak posamezni pregovor (upoštevana je srednja vrednost 3 , tj. včasih).

\begin{tabular}{|l|c|c|c|c|}
\hline & $\begin{array}{c}\text { Pregovor } \\
\text { poznam. }\end{array}$ & $\begin{array}{c}\text { Vem, kaj } \\
\text { pregovor } \\
\text { pomeni. }\end{array}$ & $\begin{array}{c}\text { Pregovor včasih } \\
\text { uporabljam pri } \\
\text { govorjenju. }\end{array}$ & $\begin{array}{c}\text { Pregovor včasih } \\
\text { uporabljam pri } \\
\text { pisanju. }\end{array}$ \\
\hline $\begin{array}{l}\text { Število } \\
\text { informantov }\end{array}$ & 157,8 & 168,1 & 45,9 & 24,8 \\
\hline$\%$ & 83,1 & 88,4 & 24,0 & 12,4 \\
\hline
\end{tabular}

Tabela 1: Povprečne vrednosti poznavanja in rabe pregovorov

Statistični podatki kažejo na to, da spadajo pregovori v veliki meri v tako imenovani pasivni del besedišča. Informanti poznajo pregovore povprečno v 83,1 \%, kar predstavlja sorazmerno visoko stopnjo poznavanja, vendar pa nam podatek ne pove ničesar o sami distribuciji poznavanja, saj predstavlja povprečno vrednost. Še višji je odstotek poznavanja pomena pregovora, vendar o tem kasneje. Informanti pregovore torej dobro poznajo, vendar pa ocenjujejo, da jih včasih uporabljajo pri govorjenju povprečno v $24 \%$, pri pisanju pa povprečno v $12,4 \%$, kar je še približno polovica prejšnje vrednosti. Nižje vrednosti za rabo pregovorov smo pričakovali, saj tudi sicer jezikoslovna literatura pregovore uvršča med pasivno besedišče. Pričakovane so tudi nižje vrednosti kar zadeva pisno rabo jezika v primerjavi z govorjenim jezikom. Presenetljive se zdijo višje vrednosti v drugem stolpcu, kjer so navedene povprečne vrednosti poznavanja pomena pregovorov. Pojasnjujemo jih tako, da so informanti pri kategoriji poznavanja pregovora odločali o tem, ali jim je pregovor poznan, medtem ko so pri drugem vprašanju ocenjevali, ali jim je poznan pomen pregovora, pri čemer je možno, da je pomen pregovora poznan, saj lahko nanj sklepamo (ali je sklepanje pravilno ali ne, anketa ni ugotavljala), medtem ko je bilo prvo vprašanje razumljeno v smislu, ali je pregovor del besednega zaklada, s katerim informant razpolaga. Pri tem koncept pasivnega obvladovanja razumemo kot sprejemanje nepoznanih jezikovnih struktur na osnovi individualnih sposobnosti govorca, da nepoznane in nove oblike kognitivno predeluje in jih vsaj zase interpretira (Ďurčo 2005: 49).

$\mathrm{V}$ tabeli 1 so navedene povprečne vrednosti poznavanja pregovorov. Pri tem so informanti (več kot 95 \%) najvišje vrednosti poznavanja pripisali naslednjim pregovorom:

Vsak začetek je težak.

Jabolko ne pade daleč od drevesa. 
Vaja dela mojstra.

Kdor čaka, dočaka.

Kdor prej pride, prej melje.

Denar je sveta vladar.

Kdor visoko leta, nizko pade.

Smeh je pol zdravja.

Rana ura, zlata ura.

Obljuba dela dolg.

Kakršen oče, takšen sin.

Manj kot $25 \%$ informantov pozna naslednja pregovora:

Pokopani živijo dlje.

Uspeh ima veliko očetov.

Marija Makarovič (1975) navaja pogoste slovenske pregovore in njihovo poznavanje deloma preverja tudi v različnih slovenskih krajih. Primerjava teh pregovorov in zgoraj naštetih najpogosteje poznanih pregovorov iz ankete pokaže, da najdemo med pregovori v zbirki Marije Makarovič samo tri, ki jim informanti v anketi pripisujejo najvišje stopnje poznavanja: Jabolko ne pade daleč od drevesa; Kdor visoko leta, nizko pade in Kdor prej pride, prej melje. Marija Makarovič (1975: 184-204) dodaja razlagam pregovorov tudi omenjeni delni pregled po regijah, v okviru katerega so informanti navedli tudi pregovore, ki jih poznajo in jih Marija Makarovič v svoji zbirki ne navaja. Med temi najdemo tri pregovore, ki ju sami navajamo med najpogosteje poznanimi, to so Rana ura, zlata ura; Kakršen oče, takšen sin in Kdor čaka, dočaka. Med njimi je velika razlika glede samih navedb informantov. Pregovora Kdor čaka, dočaka navaja samo informantka iz Lupinice pri Šmartnem, pregovor Kakršen oče, takšen sin informantka iz Križevcev pri Ljutomeru, medtem ko pregovor Rana ura, zlata ura navajajo informanti iz naslednjih krajev: Mengeš, Kališe pri Železnikih, Križevci pri Ljutomeru, Maribor, Mozirje, Podbočje, Podkoren, Predgrad ob Kolpi, Sečje selo, Sežana in Šoštanj. Sovpadanje pregovorov med seznamom, ki je nastal na osnovi naše ankete, in pregovori, ki jih navaja Marija Makarovič, je presenetljivo nizko, saj gre samo za nekaj pregovorov.

$\mathrm{V}$ analizo smo zajeli tudi podatke o rabi pregovorov, do katerih smo prišli s samoocenjevanjem informantov. Informanti so se o rabi odločali brez sobesedila, ${ }^{7}$ saj so bili pregovori zapisali izolirano. Iz podatkov analize sledi, da informanti glede na svojo lastno oceno pri govorjenju najpogosteje (več kot $40 \%$ ) uporabljajo naslednje pregovore:

Vse ima svoj čas.

Vsak začetek je težak.

Kdor visoko leta, nizko pade.

${ }^{7}$ O prednostih in slabostih glede zapisa v sobesedilu ali brez njega glej Ďurčo (2005: 49). Za zapis brez sobesedila smo se odločili na podlagi Bürgerjeve razlage (1998: 100), da so pregovori neke vrste zaprte strukture, ki jih ni nujno potrebno z dodatnimi leksikalnimi elementi povezovati s sobesedilom. 
Brez dela ni jela.

Bolje je preprečiti kot zdraviti.

Denar je sveta vladar.

Red mora biti.

Preverjanje v korpusu slovenskega jezika Nova beseda pokaže, da gre za pregovore z različnim številom navedb. Pregovora Vse ima svoj čas in Kdor visoko leta, nizko pade se v korpusu ne pojavljata, pregovor Brez dela ni jela se pojavlja 11-krat, Bolje preprečiti kot zdraviti 15-krat, Denar je sveta vladar 38-krat, najpogosteje pa se pojavljata pregovora Red mora biti (59-krat) in Vsak začetek je težak (61-krat). Ti podatki se ne ujemajo z rezultati anket. Informanti kot najpogosteje uporabljane ocenjujejo pregovore, za katere je v korpusu Nova beseda izkazana različno intenzivna stopnja rabe. Vzrok neujemanja je lahko izbor pregovorov za anketo (?), sam besedilni korpus Nova beseda ali pa samoocenjevanje informantov.

V tebeli 1 smo navedli pregovore, ki jih informanti najbolje poznajo. Primerjava s tistimi, ki jih informanti najpogosteje uporabljaju pri govorjenju, kaže, da sovpadejo samo trije pregovori: Vsak začetek je težak, Kdor visoko leta, nizko pade in Denar je sveta vladar, medtem ko se ostali razlikujejo. Celotna skupina informantov torej različno ocenjuje poznavanje in rabo pregovorov pri govorjenju, ko gre za posamezne pregovore. ${ }^{8}$

Iz podatkov analize tudi sledi, da informanti pri govorjenju najredkeje (manj kot 3,5\%) uporabljajo naslednje pregovore:

Zgodnja ptica ujame črva.

Čast komur čast.

Odličnost zavezuje.

Pokopani živijo dlje.

Zaupanje je dobro, kontrola je boljša.

Uspeh ima veliko očetov.

V korpusu Nova beseda izmed teh pregovorov najdemo samo prvega (Zgodnja ptica ujame črva), in sicer z enkratno pojavitvijo v korpusu. Takšne podatke smo pričakovali in se ujemajo s podatki analize ankete, ki jih predstavljamo.

Informanti so ocenjevali tudi rabo pregovorov pri pisanju. Iz podatkov analize sledi, da informanti pri pisanju najpogosteje (več kot $20 \%$ ) uporabljajo naslednje pregovore:

Vsak začetek je težak.

Kdor prej pride, prej melje.

Rana ura, zlata ura.

Vse ima svoj čas.

Upanje umre zadnje.

Konec dober, vse dobro.

${ }^{8} \mathrm{~V}$ nadaljevanju bomo pokazali, ali opažamo določena prekrivanja med posameznimi skupinami informantov, če jih razvrstimo po izobrazbi, spolu, starosti in kraju bivanja ter skupini informantov kot celoti. 
Čas je denar.

Motiti se je človeško.

Vaja dela mojstra.

Izmed teh v korpusu Nova beseda ni mogoče najti pregovorov: Kdor prej pride, prej melje, Rana ura, zlata ura in Konec dober, vse dobro. Z dvakratno pojavitvijo je zabeležen pregovor Vse ima svoj čas, medtem ko se ostali pojavljajo precej pogosteje: Čas je denar (46-krat), Motiti se je človeško (60-krat), Upanje umre zadnje (60-krat), Vsak začetek je težak (61-krat) in Vaja dela mojstra (74-krat). Tudi tukaj je distribucija v korpusu Nova beseda drugačna od podatkov iz ankete, vendar pa gre za nizke številke, saj informanti ocenjujejo, da navedene pregovore uporabljajo več kot $20 \%$.

$\mathrm{V}$ tebeli 1 smo navedli pregovore, ki jim informanti pripisujejo najvišje vrednosti poznavanja. Primerjava s pregovori, ki jih informanti najpogosteje uporabljajo pri pisanju, pokaže, da se ujemajo samo 4 pregovori: Vsak začetek je težak; Kdor prej pride, prej melje; Vaja dela mojstra in Rana ura, zlata ura. Vsi ostali pregovori se razlikujejo. Informanti torej različno ocenjujejo poznavanje pregovorov in njihovo rabo pri pisanju.

Iz podatkov analize sledi, da informanti pri pisanju najredkeje (več kot 1,8 \%) uporabljajo naslednje pregovore:

Zgodnja ptica ujame črva.

Pokopani živijo dlje.

Zaupanje je dobro, kontrola je boljša.

Odličnost zavezuje.

Drugi kraji, drugi običaji.

Uspeh ima veliko očetov.

V korpusu Nova beseda najdemo samo pregovor Zgodnja ptica ujame črva, ki pa se pojavlja v kontekstu interpretacije prevoda angleškega prevoda. Ostali pregovori se v korpusu ne pojavljajo. Ti rezultati se ujemajo s tem, kar pokaže analiza anket.

\subsection{Parameter izobrazba}

Podatki, pridobljene iz anket, so povezljivi tudi s podatki o jezikovnih parametrih, kot so izobrazba, spol, kraj bivanja, starost in narečna skupina. V tebeli 2 so prikazani podatki za parameter izobrazba.

Odstotki kažejo, da se poznavanje pregovorov razlikuje, in sicer raste $\mathrm{z}$ izobrazbo. Razlike so največje v kategoriji poznavanje pregovora $(16,4 \%)$ in raba pri pisanju $(11,4 \%)$ ter se linearno povečujejo z izobrazbo. Pri tem so razlike med podatki za tiste s poklicno šolo in za tiste s srednjo izobrazbo večje (10,3 \% za prvo in $10,4 \%$ za tretjo kategorijo) kot razlike med podatki za tiste $\mathrm{s}$ srednjo šolo in tiste $\mathrm{z}$ univerzitetno izobrazbo $(6,1 \%$ za prvo in $1 \%$ za tretjo kategorijo). 


\begin{tabular}{|l|c|c|c|}
\hline & OŠ $^{9}$ & SS̆$^{10}$ & UNI $^{11}$ \\
\hline Poznavanje (\%) & 72,1 & 82,4 & 88,5 \\
\hline Raba pri govorjenju ${ }^{12}(\%)$ & 17,4 & 26,8 & 24,8 \\
\hline Raba pri pisanju $^{13}$ (\%) & 3,7 & 14,1 & 15,1 \\
\hline
\end{tabular}

Tabela 2: Povprečne vrednosti za parameter izobrazba

Nekoliko drugačna slika je pri parametru raba pregovorov pri govorjenju. Tudi tukaj informanti s poklicno izobrazbo uporabljajo pregovore pri govorjenju najmanj pogosto (razlika med to skupino in skupino s srednješolsko izobrazbo znaša 9,4 \%), medtem ko sta si ostali dve skupini po številčnih vrednostih bli$\mathrm{zu}$, pri čemer so višje vrednosti pri skupini s srednješolsko izobrazbo (razlika znaša $2 \%$ ).

Glede na različne odstotke v kategorijah poznavanje in raba pri govorjenju kot tudi raba pri pisanju je smiselno preveriti tudi, za katere pregovore informanti vseh treh izobrazbenih stopenj navajajo najvišje in najnižje vrednosti.

$\mathrm{V}$ kategoriji poznavanje pregovorov smo izbrali tiste, ki jih informanti poznajo v več kot $95 \%$. Razlike so opazne in zaradi večje preglednosti pregovore navajamo $\mathrm{v}$ tabeli.

\begin{tabular}{|c|c|c|}
\hline $\begin{array}{l}\text { Skupine OŠ, SŠ in UNI } \\
\text { poznajo pregovore } 95 \% \text { > }\end{array}$ & $\begin{array}{l}\text { Skupini SŠ in UNI poznata } \\
\text { pregovore } 95 \%>\end{array}$ & $\begin{array}{l}\text { Skupina UNI pozna } \\
\text { pregovore } 95 \%>\end{array}$ \\
\hline $\begin{array}{l}\text { Vsak začetek je težak. } \\
\text { Jabolko ne pade daleč od } \\
\text { drevesa. } \\
\text { Konec dober, vse dobro. } \\
\text { Vaja dela mojstra. } \\
\text { Vsak naj pomete pred svojim } \\
\text { pragom. } \\
\text { Kdor prej pride, prej melje. } \\
\text { Hiti počasi. } \\
\text { Kdor visoko leta, nizko pade. } \\
\text { Smeh je pol zdravja. } \\
\text { Rana ura, zlata ura. } \\
\text { Ziher je ziher. } \\
\text { Obljuba dela dolg. } \\
\text { Kakršen oče, takšen sin. }\end{array}$ & $\begin{array}{l}\text { Videz vara. } \\
\text { Upanje umre zadnje. } \\
\text { Obleka naredi človeka. } \\
\text { Nikoli ne reci nikoli. } \\
\text { Kdor čaka, dočaka. } \\
\text { Ćas je denar. } \\
\text { Oko za oko, zob za zob. } \\
\text { Bolje pozno kot nikoli. } \\
\text { Roka roko umije. } \\
\text { Denar je sveta vladar. } \\
\text { Vse potrebuje svoj čas. } \\
\text { V vinu je resnica, } \\
\text { Motiti se je človeško. } \\
\text { Ljubezen je slepa. } \\
\text { Brez dela ni jela. } \\
\text { Kdor išče, ta najde. } \\
\text { Kdor riskira, profitira. } \\
\text { Kjer je volja, je tudi pot. }\end{array}$ & $\begin{array}{l}\text { Vse ima svoj čas. } \\
\text { Daleč od oči, daleč od srca. } \\
\text { Izjema potrjuje pravilo. } \\
\text { Papir vse prenese. } \\
\text { Veliko hrupa za nič. } \\
\text { Ena lastovka še ne prinese } \\
\text { pomladi. } \\
\text { Kdor ne dela, naj ne je. } \\
\text { Nasprotja se privlačijo. } \\
\text { Red mora biti. } \\
\text { Maščevanje je sladko. } \\
\text { Bolje je preprečiti kot } \\
\text { zdraviti. } \\
\text { Kakor dobljeno, tako } \\
\text { izgubljeno. } \\
\text { Vsi smo v istem čolnu. }\end{array}$ \\
\hline
\end{tabular}

Tabela 3: Poznavanje pregovorov glede na izobrazbo

\footnotetext{
${ }^{9}$ Osnovnošolska izobrazba ali poklicna izobrazba.

${ }^{10}$ Srednješolska izobrazba.

${ }^{11}$ Univerzitetna izobrazba.

${ }^{12}$ Srednja vrednost včasih.

${ }^{13}$ Srednja vrednost včasih.
} 
Informanti iz vseh treh skupin poznajo 13 pregovorov v več kot $95 \%$. Informanti iz skupine s srednješolsko izobrazbo poznajo v več kot $95 \%$ še nadaljnjih 17 pregovorov, ki jih v več kot $95 \%$ poznajo tudi informanti iz skupine tistih z univerzitetno izobrazbo. Slednji pa poznajo v več kot $95 \%$ še nadaljnjih 13 pregovorov. $^{14}$

Informanti iz vseh treh skupin so navedli tudi različne pregovore, ki jih uporabljajo pri govorjenju. Navajamo jih $\mathrm{v}$ tabeli 4 , vendar ločeno po posameznih skupinah, in sicer navajamo samo tiste pregovore, ki jih informanti uporabljajo najpogosteje.

\begin{tabular}{|l|l|l|}
\hline Skupina OŠ & Skupina SS̆ & Skupina UNI \\
\hline Vsak naj pomete pred svojim & Nikoli ne reci nikoli. & Jabolko ne pade daleč od \\
pragom. & Vaja dela mojstra. & Videz vara. \\
Kdor ne dela, naj ne je. & Kdor čaka, dočaka. & Nikoli ne reci nikoli. \\
Rana ura, zlata ura. & Vsak naj pomete pred svojim & Vaja dela mojstra. \\
Brez dela ni jela. & pragom. & Kdor čaka, dočaka. \\
Ziher je ziher. & Smeh je pol zdravja. & Vsak naj pomete pred svojim \\
Kdor išče, ta najde. & Rana ura, zlata ura. & pragom. \\
& Ziher je ziher. & Kdor prej pride, prej melje. \\
& & Smeh je pol zdravja.. \\
& & Rana ura, zlata ura.. \\
& & Ziher je ziher. \\
\hline
\end{tabular}

Tabela 4: Najpogosteje uporabljani pregovori pri govorjenju glede na izobrazbo

Med najpogostejšimi v vseh treh skupinah se pojavljajo trije pregovori: Vsak naj pomete pred svojim pragom, Rana ura, zlata ura in Ziher je ziher, sicer pa je opazno večje ujemanje med skupinama SŠ in UNI kot med OŠ in drugima dvema skupinama. To ujemanje korelira tudi z ujemanjem s podatki iz tabele 2 , kjer je raba pri govorjenju prikazana v odstotkih.

$\mathrm{V}$ tebeli $3 \mathrm{v}$ prvem stolpcu navajamo pregovore, ki jih najbolje poznajo informanti iz vseh treh skupin. Večino jih najdemo tudi v tabeli 4, ki prikazuje pogostnost uporabe pri govorjenju, kar pomeni, da gre za pregovore, ki so dobro prepoznani in pogosto uporabljani pri različnih izobrazbenih skupinah. Vse tri skupine navajajo naslednje pregovore kot najpogosteje uporabljane in obenem najbolje poznane: Vsak naj pomete pred svojim pragom, Rana ura, zlata ura in Ziher je ziher. Dva pregovora - Vaja dela mojstra in Smeh je pol zdravja - sta med najbolje poznanimi in najpogosteje uporabljanimi pri skupinah SŠ in UNI, pregovora Jabolko ne pade daleč od drevesa in Kdor prej pride, prej melje pa

${ }^{14} \mathrm{O}$ položaju frazemov v kurikularnih dokumentih za slovenske šole primerjaj Kacjan in Jazbec (2012). Dodatna raziskava bi lahko izpostavila pregovore v omenjenih dokumentih in problematizirala njihovo pojavljanje. Sicer pa tudi ne poznamo raziskave, ki bi natančneje ugotavljala vire usvajanja pregovorov, predvsem razmerja med formalnim in neformalnim izobraževanjem. 
sta med najbolje poznanimi in najpogosteje uporabljanimi pri govorjenju pri skupini UNI.

V naslednji tabeli navajamo pregovore, ki jih informanti iz različnih izobrazbenih skupin navajajo kot tiste, ki jih najpogosteje uporabljajo pri pisanju.

\begin{tabular}{|l|l|l|}
\hline Skupina OŠ & Skupina Š̆ & Skupina UNI \\
\hline Kjer je volja, je tudi pot. & Nikoli ne reci nikoli. & Nikoli ne reci nikoli. \\
& Vaja dela mojstra. & Vaja dela mojstra. \\
& Smeh je pol zdravja. & Vse potrebuje svoj čas. \\
& Ziher je ziher. & $\begin{array}{l}\text { Smeh je pol zdravja. } \\
\text { Kjer je volja, je tudi pot. }\end{array}$ \\
\hline
\end{tabular}

Tabela 5: Najpogosteje uporabljani pregovori pri pisanju glede na izobrazbo

Pri pisanju informanti uporabljajo manj pregovorov na splošno, kar kaže primerjava odstotkov iz tabele 2 , razlike znašajo od 10 do $14 \%$. Katere pregovore uporabljajo najpogosteje, kaže tabela 5, pri čemer se noben pregovor ne pojavlja pri vseh treh skupinah. Nekaj prekrivanja je med dvema skupinama: prvi trije pregovori iz stolpca SS se pojavljajo tudi v stolpcu UNI in pregovor iz stolpca OŠ se pojavlja tudi v stolpcu UNI. V stolpcu SŠ in stolpcu UNI se pojavljata pregovora, ki ju v drugih dveh stolpcih ni najti. Zanimivo je pogosto pojavljanje pregovora Ziher je ziher v skupini SŠ. Pregovor zaznamuje element germanizma (ziher) in presenetljivo je, da ga informanti označujejo kot pregovor, ki ga uporabljajo pri pisanju. Kadar pišemo, običajno pišemo v knjižnem jeziku, obstaja pa vrsta besedilnih vrst, kjer ne uporabljamo nujno knjižnega jezika. Žal nam anketa ne daje podatkov o tem, katere besedilne vrste so imeli informanti $\mathrm{v}$ mislih, ko so anketo izpolnjevali. Ta pregovor je tudi pogosto označen kot pregovor, ki je dobro poznan in se pogosteje uporablja, zato je mogoče, da so se informanti deloma odločali tudi po inerciji in mu pripisovali večjo pogostnost pri pisanju.

Pregovori iz tabele 5 se z izjemo pregovora Kjer je volja, je tudi pot pojavljajo tudi v tabeli 3, kjer so zbrani pregovori, ki jih informanti iz posameznih skupin najbolje poznajo. Torej lahko sklepamo, da informanti pri pisanju največkrat uporabljajo tiste pregovore, za katere navajajo, da jih v veliki večini tudi poznajo.

Pregovori iz tabele $5 \mathrm{se} \mathrm{z} \mathrm{izjemo} \mathrm{pregovorov} \mathrm{Kjer} \mathrm{je} \mathrm{volja,} \mathrm{je} \mathrm{tudi} \mathrm{pot} \mathrm{in} \mathrm{Vse}$ potrebuje svoj čas pojavljajo tudi v tabeli 4, kjer so zbrani pregovori, ki jih informanti najpogosteje uporabljajo pri govorjenju. Torej lahko sklepamo, da informanti pri pisanju večinoma uporabljajo tiste pregovore, ki jih najpogosteje uporabljajo tudi pri govorjenju. 


\subsection{Parameter kraj bivanja}

Informanti prihajajo iz različnih krajev Slovenije, večina od njih živi ali je najdaljši del življenja preživela $\mathrm{v}$ manjših krajih in vaseh, edino večje mesto $\mathrm{v}$ odgovorih je Maribor. Zato v tem podpoglavju prikazujemo podatke o poznavanju in rabi pregovorov ločeno za dve skupini: Maribor in vsi ostali kraji (manjša mesta, vasi iz vseh treh narečnih skupin). Tudi tukaj navajamo sredinske, tj. povprečne vrednosti (vrednost 3 na lestvici v anketi), in sicer pri kategorijah o rabi pri govorjenju oz. pisanju, medtem ko za prvi dve kategoriji navajamo deleže pozitivnih odgovorov.

\begin{tabular}{|c|c|c|c|c|c|c|c|c|}
\hline & \multicolumn{2}{|c|}{ Poznavanje } & \multicolumn{2}{c|}{$\begin{array}{c}\text { Poznavanje } \\
\text { pomena }\end{array}$} & \multicolumn{2}{c|}{$\begin{array}{c}\text { Raba pri } \\
\text { govorjenju }^{15}\end{array}$} & \multicolumn{2}{c|}{ Raba pri pisanju } \\
& MB & ostali & MB & ostali & MB & ostali & MB & ostali \\
\hline$\%$ & 82,1 & 84,1 & 86,9 & 89,8 & 23,2 & 24,8 & 10,9 & 14 \\
\hline
\end{tabular}

Tabela 6: Povprečne vrednosti za parameter kraj bivanja

V tabeli se kaže nekaj razlik, ki pa ne presegajo 4 \%. Vse kažejo na boljše poznavanje, razumevanje in pogostejšo rabo tako pri govorjenju kot pri pisanju pri informantih, ki ne živijo v Mariboru. Skupno število informantov je 189, tistih iz Maribora je 55, kar lahko pomeni, da so deleži za Maribor zavajajoči, saj število informantov ni veliko. Ker pa je sámo število pregovorov sorazmerno veliko, rezultatom pripisujemo določeno mero relevantnosti.

Tako kot so primerljivi rezultati v tabeli 6, so primerljivi tudi sami pregovori, za katere informanti najpogosteje navajajo, da jih poznajo. Navajamo tiste pregovore, ki jih pozna $95 \%$ informantov ali več. Kot je razvidno s seznama, gre za identično listo pregovorov:

Vsak začetek je težak.

Jabolko ne pade daleč od drevesa.

Vaja dela mojstra.

Kdor čaka, dočaka.

Kdor prej pride, prej melje.

Denar je sveta vladar.

Kdor visoko leta, nizko pade.

Smeh je pol zdravja.

Rana ura, zlata ura.

Obljuba dela dolg.

Kakršen oče, takšen sin.

Samo dva pregovora informanti poznajo v manj kot $25 \%$ : Pokopani živijo dlje in Zgodnja ptica ujame črva. Tudi tukaj ni razlike med informanti iz Maribora in tistimi iz ostalih krajev.

15 Srednja vrednost včasih.

${ }^{16}$ Srednja vrednost včasih. 
Tudi seznam pregovorov, za katere informanti v najvišjih odstotkih navajajo, da poznajo njihov pomen, je identičen za obe skupini (MB, ostali kraji):

Vsak začetek je težak.

Vaja dela mojstra.

Kdor čaka, dočaka.

Kdor prej pride, prej melje.

Denar je sveta vladar.

Kdor visoko leta, nizko pade.

Rana ura, zlata ura.

Obljuba dela dolg.

Identični v obeh skupinah so tudi pregovori, katerih pomen pozna najmanj informantov: Čast komur čast, Pokopani živijo dlje, Zgodnja ptica ujame črva.

Razlike med skupinama (MB, ostali) se delno kažejo pri kategoriji raba pregovorov pri govorjenju. V tabeli 7 so navedeni pregovori, ki jih pri govorjenju najpogosteje uporabljajo informanti iz obeh skupih.

\begin{tabular}{|l|l|}
\hline Maribor & Ostali \\
\hline Vse ima svoj čas. & Vse ima svoj čas. \\
Vsak začetek je težak. & Denar je sveta vladar. \\
Kdor visoko leta, nizko pade. & Brez dela ni jela. \\
Brez dela ni jela. & Bolje je preprečiti kot zdraviti. \\
Bolje je preprečiti kot zdraviti. & Kdor visoko leta, nizko pade. \\
& Red mora biti. \\
\hline
\end{tabular}

Tabela 7: Najpogosteje rabljeni pregovori pri govorjenju po kraju bivanja

Razlike so opazne pri treh pregovorih. Informanti iz Maribora pri govorjenju pogosto uporabljajo pregovor Vsak začetek je težak, ki mu ostali informanti ne pripisujejo pogoste uporabe. Medtem pa informanti, ki niso najdlje časa živeli v Mariboru, pri govorjenju pogosto uporabljajo naslednja pregovora: Denar je sveta vladar, Red mora biti, ki pa ju informanti iz Maribora pri govorjenju ne uporabljajo pogosto.

$\mathrm{V}$ tabeli 8 so prikazani najredkeje rabljeni pregovori glede na kraj bivanja.

\begin{tabular}{|l|l|}
\hline Maribor & Ostali \\
\hline Zgodnja ptica ujame črva. & Zgodnja ptica ujame črva. \\
Čast komur čast. & Pokopani živijo dlje. \\
Odličnost zavezuje. & Uspeh ima veliko očetov. \\
Pokopani živijo dlje. & Čast komur čast. \\
Zaupanje je dobro, kontrola je boljša. & Zaupanje je dobro, kontrola je bolǰ̌a. \\
Uspeh ima veliko očetov. & Odličnost zavezuje. \\
\hline
\end{tabular}

Tabela 8: Najredkeje rabljeni pregovori pri govorjenju glede na kraj bivanja 
Gre za dva identična seznama, ki se razlikujeta v posameznih odstotkih, vendar so tudi tukaj opazne vzporednice.

$\mathrm{V}$ tabeli 9 so navedeni pregovori, ki jih informanti obeh skupin (MB, ostali) najpogosteje uporabljajo pri pisanju.

\begin{tabular}{|l|l|}
\hline Maribor & Ostali \\
\hline Vsak začetek je težak. & Vsak začetek je težak. \\
Kdor prej pride, prej melje. & Vse ima svoj čas. \\
Rana ura, zlata ura. & Upanje umre zadnje. \\
Vse ima svoj čas. & Vaja dela mojstra. \\
Upanje umre zadnje. & Kdor prej pride, prej melje. \\
Konec dober, vse dobro. & Čas je denar. \\
Čas je denar. & Motiti se je človeško. \\
Motiti se je človeško. & Konec dober, vse dobro. \\
\hline
\end{tabular}

Tabela 9: Najpogosteje rabljeni pregovori pri pisanju glede na kraj bivanja

Večina pregovorov se pojavlja $\mathrm{v}$ obeh skupinah, razlika je samo $\mathrm{v}$ frekvenci pregovorov: Rana ura, zlata ura je med najpogosteje uporabljanimi pregovori v Mariboru, Vaja dela mojstra pa med najpogosteje uporabljanimi pregovori ostalih informantov.

V tabeli 10 so navedeni pregovori, ki jih informanti obeh skupin (MB, ostali) najredkeje uporabljajo pri pisanju.

\begin{tabular}{|l|l|}
\hline Maribor & Ostali \\
\hline Zgodnja ptica ujame črva. & Zgodnja ptica ujame črva. \\
Pokopani živijo dlje. & Pokopani živijo dlje. \\
Zaupanje je dobro, kontrola je boljša. & Zaupanje je dobro, kontrola je boljša. \\
Odličnost zavezuje. & Čast komur čast. \\
Drugi kraji, drugi običaji. & Odličnost zavezuje. \\
Uspeh ima veliko očetov. & Uspeh ima veliko očetov. \\
\hline
\end{tabular}

Tabela 10: Najredkeje rabljeni pregovori pri pisanju glede na kraj bivanja

Tudi v tem primeru gre za skorajda identične pregovore, razlika je le v dveh pregovorih: Drugi kraji, drugi običaji je pregovor, ki je med najredkeje uporabljanimi pregovori pri pisanju pri informantih iz Maribora, Čast komur čast pa pri ostalih informantih.

\subsection{Parameter spol}

Analiza podatkov za parameter spol ni pokazala signifikantnih razlik: informantke poznajo v povprečju 83,9\%, informanti pa 81,6 \% pregovorov. Statistične podatke prikazuje tabela 11 . 
Zasidranost pregovorov v besedišču govorcev slovenskega jezika

\begin{tabular}{|c|c|c|}
\hline & Informantke & Informanti \\
\hline Poznavanje (\%) & 83,9 & 81,6 \\
\hline Raba pri govorjenju ${ }^{17}(\%)$ & 23,9 & 25,7 \\
\hline Raba pri pisanju ${ }^{18}(\%)$ & 14,6 & 9,1 \\
\hline
\end{tabular}

Tabela 11: Poznavanje in raba pregovorov glede na spol

Opaznejše razlike v številčnih vrednostih so pri kategoriji raba pregovora pri pisanju, kjer informantke navajajo za 5,5 \% višje vrednosti. V tabeli 12 so navedeni pregovori, ki jih informantke in informanti najpogosteje uporabljajo pri pisanju, in sicer tisti, ki so jim bile v anketi pripisane najvišje vrednosti v kategoriji včasih, torej srednje vrednosti.

\begin{tabular}{|l|l|}
\hline Raba pri pisanju (informantke) & Raba pri pisanju (informanti) \\
\hline Vse ima svoj čas. & Upanje umre zadnje. \\
Vsak začetek je težak. & Kdor prej pride, prej melje. \\
Papir vse prenese. & Nasprotja se privlačijo. \\
Nikoli ne reci nikoli. & Motiti se je človeško. \\
Vaja dela mojstra. & Ziher je ziher. \\
Upanje umre zadnje. & Kdor išče, ta najde. \\
Kdor čaka, dočaka. & Znanje je moč. \\
Vsak naj pomete pred svojim pragom. & \\
Čas je denar. & \\
Rana ura, zlata ura. & \\
Kdor išče, ta najde. & \\
\hline
\end{tabular}

Tabela 12: Najpogosteje rabljeni pregovori pri pisanju glede na spol

Iz tabele je razvidno, da se samo dva pregovora pojavljata pri obeh skupinah: Upanje umre zadnje in Kdor išče, ta najde. Pregovor Upanje umre zadnje najdemo med najpogostejšimi pregovori tudi v tabeli 9 (v stolpcu pregovorov za Maribor) in med pregovori, ki jih na splošno vsi informanti pogosto uporabljajo pri pisanju, pregovora Kdor išče, ta najde pa ne najdemo na seznamih ali v drugih tabelah.

\subsection{Parameter starost}

V anketnem vprašalniku so informanti navedli tudi podatke o svoji starosti, in sicer smo jih razvrstili v štiri starostne skupine: do 25 let, od 26 do 50 let, od 51 do 64 let in nad 65 let. Poznavanje pregovorov glede na starostne skupine prikazuje tebela 13, pri čemer sta bili dve starejši starostni skupini združeni, saj

\footnotetext{
${ }^{17}$ Srednja vrednost včasih.

18 Srednja vrednost včasih.
} 
ju skupaj tvori 42 informantov, deljeno pa bi v tretjo starostno skupino (51-64 let) uvrstili 28 informantov, v četrto (nad 65 let) pa samo 14 informantov, kar je kljub relativno visokemu številu pregovorov premalo za statistično obdelavo podatkov.

\begin{tabular}{|l|c|c|c|}
\hline & Do 25 let & $26-50$ let & Nad 51 let \\
\hline Poznavanje (\%) & 81,1 & 70,8 & 80,0 \\
\hline Raba pri govorjenju ${ }^{19}$ (\%) & 21,1 & 25,5 & 25,6 \\
\hline Raba pri pisanju ${ }^{20}(\%)$ & 15,01 & 14,0 & 7,4 \\
\hline
\end{tabular}

Tabela 13: Povprečne vrednosti za parameter starost

Po podatkih iz tabele 13 pregovore najbolje poznajo informanti iz skupine do 25 let, sledijo jim tisti iz skupine nad 50 let, pri čemer je razlika med tema dvema skupinama samo 1,1\%. Razlika med tema skupinama in skupino od 26-50 let je precejšnja, znaša namreč 9,2 \% (druga : tretja starostna skupina) oz. $10,3 \%$ (prva : druga starostna skupina). Čemu lahko pripišemo to razliko? Glede na podatke iz zgornje tabele ne moremo trditi, da je povezljiva s podatki o uporabi pregovorov pri govorjenju in pisanju oziroma $\mathrm{z}$ eno od teh kategorij.

$\mathrm{V}$ tabeli 14 po starostnih skupinah navajamo pregovore, za katere so vsi informanti navedli, da jih poznajo.

\begin{tabular}{|l|l|l|}
\hline Vse tri skupine & Prva in tretja skupina & Druga in tretja skupina \\
\hline Jabolko ne pade daleč od & Kdor prej pride, prej melje. & Denar je sveta vladar. \\
drevesa. & Rana ura, zlata ura. & Brez dela ni jela. \\
Vaja dela mojstra. & Obljuba dela dolg. & \\
Kdor visoko leta, nizko pade. & Kakršen oče, takšen sin. & \\
Smeh je pol zdravja. & & \\
\hline
\end{tabular}

Tabela 14: Najpogosteje poznani pregovori glede na starost

Vsi informanti vseh treh skupin poznajo štiri pregovore (od 67), štiri jih poznata prva in tretja skupina in dva še druga in tretja skupina. To deloma preseneča, saj bi pričakovali, da se bo več pregovorov pojavilo pri vseh treh skupinah. Med pregovori v anketi je veliko takih, ki jih informanti poznajo (več kot $80 \%$ in vprašanje je, koliko je samo poznavanje glede na starostne skupine lahko tudi naključno.

Kar zadeva rabo pregovorov se skupine razlikujejo predvsem glede rabe pregovorov pri pisanju, manjše razlike so pri rabi v govorjenju. Katere pregovore informanti iz posameznih starostnih skupin najpogosteje uporabljajo pri govorjenju?

\footnotetext{
19 Srednja vrednost včasih.

${ }^{20}$ Srednja vrednost včasih.
} 


\begin{tabular}{|l|l|l|}
\hline Do 25 let & 26-50 let & Nad 51 let \\
\hline Upanje umre zadnje. & Nikoli ne reci nikoli. & Jabolko ne pade daleč od \\
Nikoli ne reci nikoli. & Vaja dela mojstra. & drevesa. \\
Vaja dela mojstra. & Kdor čaka, dočaka. & Smeh je pol zdravja. \\
Vsak naj pomete pred svojim & Vsak naj pomete pred svojim & Rana ura, zlata ura. \\
pragom. & pragom. & Brez dela ni jela.. \\
Kdor prej pride, prej melje. & Smeh je pol zdravja. & Ziher je ziher. \\
Smeh je pol zdravja. & Rana ura, zlata ura. & Kdor iše, ta najde. \\
Ziher je ziher. & Ziher je ziher. & \\
\hline
\end{tabular}

Tabela 15: Najpogosteje rabljeni pregovori pri govorjenju glede na starostno skupino

Zelo pogosto informanti vseh treh starostnih skupin uporabljajo samo dva pregovora, in sicer Smeh je pol zdravja in Ziher je ziher. Trije pregovori (Nikoli ne reci nikoli, Vaja dela mojstra in Vsak naj pomete pred svojim pragom) se pojavljajo pri prvi in drugi starostni skupini, medtem ko tretja starostna skupina opazno odstopa v smislu, da so med najpogosteje uporabljanimi pregovori trije, ki jih drugi dve skupini ne navajata, in to Jabolko ne pade daleč od drevesa, Brez dela ni jela in Kdor išče, ta najde. Nadaljnje raziskave bi pokazale, ali lahko pri določenih starostnih skupinah govorimo o tipičnih predstavnikih pregovorov, ki se pogosteje uporabljajo, kar je možno umestiti v kulturni, starostni in izobrazbeni kontekst.

V naslednji tabeli so za vse tri starostne skupine navedeni pregovori, ki jih informanti najpogosteje uporabljajo pri pisanju.

\begin{tabular}{|l|l|l|}
\hline Do 25 let & 26-50 let & Nad 51 let \\
\hline Upanje umre zadnje. & Nikoli ne reci nikoli. & Vaja dela mojstra. \\
Nikoli ne reci nikoli. & Vaja dela mojstra. & Rana ura, zlata ura. \\
Vaja dela mojstra. & Vse potrebuje svoj čas. & Obljuba dela dolg. \\
Kdor čaka, dočaka. & Kdor visoko leta, nizko pade. & Bolje je preprečiti kot \\
Kdor prej pride, prej melje. & Smeh je pol zdravja. & zdraviti. \\
Smeh je pol zdravja. & Obljuba dela dolg. & Kjer je volja, je tudi pot. \\
Ziher je ziher. & Kjer je volja, je tudi pot. & \\
\hline
\end{tabular}

Tabela 16: Najpogosteje rabljeni pregovori pri pisanju glede na starostno skupino

Pri vseh treh starostnih skupinah je naveden samo pregovor Vaja dela mojstra, pregovor Nikoli ne reci nikoli je naveden pri prvi in drugi starostni skupini, pregovora Obljuba dela dolg in Kjer je volja, je tudi pot pri drugi in tretji starostni skupini, ostali se razlikujejo. Pri kategoriji uporaba pregovora pri pisanju je torej še manj prekrivanja kot pri kategoriji uporaba pri govorjenju.

Kar zadeva najpogostejše pojavljanje pregovorov po posameznih starostnih skupinah in primerjalno pri obeh kategorijah, pa ugotavljamo, da informanti prve starostne skupine najpogosteje uporabljajo iste pregovore pri obeh načinih jezikovnega sporazumevanja, izjemi sta pregovora Vsak naj pomete pred svojim pragom in Kdor čaka, dočaka. 
Pri informantih iz druge starostne skupine je ujemanje pri govorjenju in pri pisanju opazno pri treh pregovorih: Nikoli ne reci nikoli, Vaja dela mojstra in Smeh je pol zdravja, medtem ko se ostali pregovori razlikujejo.

Še večje razlikovanje je opaziti pri tretji starostni skupini, kjer je med najpogosteje uporabljanimi pregovori tako pri govorjenju kot pri pisanju samo pregovor Rana ura, zlata ura, vsi ostali se razlikujejo. Tudi tukaj bi nam širše zasnovana raziskava pomagala podkrepiti in pojasniti omenjene razlike med starostnimi skupinami.

\subsection{Parameter narečja}

Informanti, ki so sodelovali pri izpolnjevanju ankete, so v tej navedli tudi, v katerem kraju so živeli najdlje časa. Na osnovi tega podatka smo jih razdelili $\mathrm{v}$ tri narečne skupine, to so štajerska, panonska in koroška (anketiranje je bilo izvedeno samo v Sloveniji). Pet informantov, ki so najdlje živeli na območju, kjer se ne govorijo omenjena narečja, smo izločili iz statistične obdelave podatkov. Ostale informante številčno delimo glede na narečne skupine: štajerska (75 anket), panonska (42 anket) in koroška narečna skupina (67 anket). Podatki statistične obdelave odgovorov v anketi nam omogočajo, da preverimo, ali se poznavanje in raba pregovorov razlikujeta glede na narečne skupine. Možno bi jih bilo sicer razdeliti tudi po posameznih narečjih, vendar bi bila v tem primeru statistična relevantnost vprašljiva.

V tabeli 17 so prikazani podatki, ki se nanašajo na prvo kategorijo v anketi, to je poznavanje pregovorov.

\begin{tabular}{|c|c|c|c|}
\hline & ŠTA $^{21}$ & $\mathrm{PAN}^{22}$ & $\mathrm{KOR}^{23}$ \\
\hline Poznavanje (\%) & 82,5 & 80,7 & 85,5 \\
\hline Raba pri govorjenju ${ }^{24}(\%)$ & 22,8 & 23,3 & 26 \\
\hline Raba pri pisanju ${ }^{25}(\%)$ & 13,1 & 13,2 & 13,4 \\
\hline
\end{tabular}

Tabela 17: Povprečne vrednosti za parameter narečna skupina

Razlike ne presegajo $5 \%$, pri čemer so manjše med štajersko in panonsko narečno skupino kot med njima in koroško narečno skupino. Na podlagi rezultatov ankete je težko govoriti o povezanosti govornega prostora v taki meri, da bi lahko z njo utemeljevali manjše razlike med štajersko in panonsko narečno skupino. Za to bi bilo treba opraviti obsežnejšo leksikološko študijo, s katero

${ }^{21}$ Štajerska narečja.

${ }^{22}$ Panonska narečja.

${ }^{23}$ Koroška narečja, natančneje podjunsko narečje (v Sloveniji).

${ }^{24}$ Srednja vrednost včasih.

${ }^{25}$ Srednja vrednost včasih. 
bi določili areale posameznih leksemov in njihov pomenski obseg. ${ }^{26}$ Deloma povezanost posameznih narečnih prostorov nakazuje tudi naslednja tabela.

Različni odstotki, kar zadeva poznavanje pregovorov, se kažejo tudi v tem, katere pregovore poznajo vsi informanti v vsaki posamezni narečni skupini, kar je razvidno iz naslednje tabele.

\begin{tabular}{|l|l|l|}
\hline Vsi informanti & Vsi informanti & $\begin{array}{l}\text { Vsi informanti } \\
\text { ŚTA, KOR }\end{array}$ \\
\hline Sabolko ne pade daleč od & STA, PAN & Vsak začetek je težak. \\
drevesa. & Denar je sveta vladar. & pragom. \\
Vaja dela mojstra. & Rana ura, zlata ura. \\
Kdor prej pride, prej melje. & Kakršen oče, takšen sin. & \\
Kdor visoko leta, nizko pade. & & \\
Smeh je pol zdravja. & & \\
Obljuba dela dolg. & & \\
\hline
\end{tabular}

Tabela 18: Pregovori, ki jih poznajo vsi informanti ŠTA, PAN, KOR narečne skupine

Tabela kaže, da se več istih pregovorov pojavlja v štajerski in panonski narečni skupini.

Kar nekaj pregovorov poznajo vsi informanti iz samo ene narečne skupine. Tako poznajo vsi informanti iz skupine štajerskih narečij pregovor Kdor čaka, dočaka, vsi informanti iz skupine panonskih narečij pregovore: Konec dober, vse dobro; Obleka naredi človeka; Kdor ne dela, naj ne je; Brez dela ni jela in Ziher je ziher, vsi informanti s področja koroškega podjunskega narečja pa pregovore: Upanje umre zadnje; Nikoli ne reci nikoli; Bolje pozno kot nikoli; Roka roko umije; Ljubezen je slepa; Nova metla dobro pometa in Kdor išče, ta najde.

Tudi v kategoriji uporaba pregovorov pri govorjenju smo poiskali pregovore, ki jih informanti najpogosteje uporabljajo, in jih v tabeli 19 razvrstili po posameznih narečnih skupinah.

\begin{tabular}{|l|l|l|}
\hline ŠTA & PAN & KOR \\
\hline Upanje umre zadnje. & Vaja dela mojstra. & Nikoli ne reci nikoli. \\
Nikoli ne reci nikoli. & Vsak naj pomete pred svojim & Vaja dela mojstra. \\
Vaja dela mojstra. & pragom. & Kdor čaka, dočaka. \\
Vsak naj pomete pred svojim & Kdor prej pride, prej melje. & Vsak naj pomete pred svojim \\
pragom. & Rana ura, zlata ura. & pragom. \\
Smeh je pol zdravja. & Ziher je ziher. & Smeh je pol zdravja. \\
Ziher je ziher. & & Ziher je ziher. \\
\hline
\end{tabular}

Tabela 19: Najpogosteje uporabljeni pregovori pri govorjenju in po posameznih narečnih skupinah

${ }^{26}$ Več o tem za prekmursko in koroško poljedelsko leksiko glej pri Benko in Koletnik (2011, 2013). 
Pregovori v zgornji tabeli nam pokažejo, da je prekrivanje med posameznimi narečnimi skupinami kar precejšnje. Pregovori Vaja dela mojstra; Vsak naj pomete pred svojim pragom in Ziher je ziher so znani povsod, pregovora Nikoli ne reci nikoli in Smeh je pol zdravja sta najpogostejša v štajerski in koroški narečni skupini, nekaj jih je znanih samo v posameznih narečnih skupinah. Prekrivanje podatkov za posamezne narečne skupine pri rabi v govoru je vsekakor večje kot pri samem poznavanju pregovorov.

Pregovori, ki jih informanti v posameznih narečnih skupinah najpogosteje uporabljajo pri pisanju, so navedeni v tabeli 20.

\begin{tabular}{|l|l|l|}
\hline ŠTA & PAN & KOR \\
\hline Nikoli ne reci nikoli. & Jabolko ne pade daleč od drevesa. & Vsak naj pomete pred \\
Vaja dela mojstra. & Nikoli ne reci nikoli. & svojim pragom. \\
Kdor čaka, dočaka. & Vaja dela mojstra. & Denar je sveta vladar. \\
Smeh je pol zdravja. & Kdor visoko leta, nizko pade. & Vse potrebuje svoj čas. \\
Ziher je ziher. & Smeh je pol zdravja. & Smeh je pol zdravja. \\
Obljuba dela dolg. & Rana ura, zlata ura. & Rana ura, zlata ura. \\
Kjer je volja, je tudi pot. & Ziher je ziher. & Kjer je volja, je tudi pot. \\
\hline
\end{tabular}

Tabela 20: Najpogosteje uporabljeni pregovori pri pisanju in po posameznih narečnih skupinah

Pri pisanju je v vseh treh narečnih skupinah najpogostejši pregovor Smeh je pol zdravja. Pregovori Nikoli ne reci nikoli, Vaja dela mojstra in Ziher je ziher se pojavljajo v štajerski in panonski narečni skupini, medtem ko je prekrivanja s koroško narečno skupino manj. Pregovor Rana ura, zlata ura najdemo v panonski in koroški narečni skupini, pregovor Kjer je volja, je tudi pot pa v štajerski in koroški narečni skupini. Tudi ti podatki iz tabele potrjujejo večjo povezanost med panonsko in štajersko narečno skupino.

\subsection{Sklep}

Kot sklep izpostavljamo tiste izsledke analize po posameznih parametrih, ki so pokazale določene težnje, in tiste, kjer so statistični podatki dovolj pomenljivi: 1) pregovori so pretežno pasivni del besedišča;

2) pregovori se pogosteje uporabljajo pri govorjenju kot pri pisanju;

3) poznavanje in raba pregovorov sta povezana z izobrazbo informantov;

4) poznavanje in raba pregovorov sta povezana s starostjo informantov;

5) glede poznavanja in rabe pregovorov se kaže delna povezanost štajerske in panonske narečne skupine.

Statistična analiza je pokazala, da informanti pregovore sorazmerno dobro poznajo, jih pa v veliko manjši meri uporabljajo. Pregovore prepoznavajo, menijo, da poznajo njihov pomen, vendar pa jih redko uporabljajo. Sama anketa nam ne 
daje podatkov o kontekstu, v katerem informanti uporabljajo pregovore, prav tako nam ne pove, v katerem kontekstu jih srečujejo in prepoznavajo, kakšen odnos imajo do njih oz. kako pomembna se jim zdita njihovo poznavanje in uporaba. To presega okvir že tako obsežne ankete.

Informanti uporabljajo pregovore pogosteje pri govorjenju kot pri pisanju, pri čemer jih nismo spraševali po besedilnih vrstah, ki jih tvorijo. Večja pogostnost pri govorjenju je povezljiva tudi s tem, da je ustnega sporočanja v vsakodnevni rabi neprimerno več kot pisnega.

Linearno z višjo stopnjo izobrazbe se povečujeta tudi poznavanje in uporaba pregovorov. Pregovori očitno sodijo v besedišče, ki je vsaj deloma vezano na intelektualno izobrazbo oziroma velja za znak izobraženosti. Danes pregovori izgubljajo svojo didaktično vlogo, torej se počasi selijo na področje intektualnega izziva. Samo na tak način lahko pojasnimo rast poznavanja in rabe linearno z izobrazbo. Število informantov je gotovo dovolj veliko, da pri konotacijah z izobrazbo ne moremo govoriti o naključju.

Večje razlike pri parametru starost so se pokazale pri rabi pregovorov pri pisanju, kjer najstarejša starostna skupina ocenjuje, da pregovore najredkeje uporablja pri pisanju, medtem ko sta drugi dve starostni skupini primerljivi. Rezultat je gotovo povezljiv s pisnim sporočanjem kot takim. Mlajša in srednja generacija sta aktivnejši, kar zadeva dnevno pisno sporočanje.

Poznavanje in raba pregovorov, tudi posameznih, kažeta delno povezljivost štajerskega in panonskega narečnega prostora. To opažanje bi lahko podkrepili ali ovrgli le na podlagi izsledkov širše zasnovane leksikološke študije.

\section{LITERATURA}

Roger D. ABRAHAMS, 1975: A Sociolingustic Approach to Proverbs. Midwestern Journal of Language and Folklore 1/1, 60-64.

Saša BABIČ, 2011: Paremiologija - na križišču jezikoslovja in slovstvene folkloristike. Meddisciplinarnost $v$ slovenistiki. Ur. Simona Kranjc. Ljubljana: Filozofska fakulteta, 27-32.

Anja BENKO, Mihaela KOLETNIK, 2011: Primerjalni terminološki narečni slovar (za izbrano besedje s področja poljedelstva). Izzivi sodobnega slovenskega slovaropisja. Ur. Marko Jesenšek. Maribor: Mednarodna založba Oddelka za slovanske jezike in književnosti. (Zora, 75). 103-125.

Anja BENKO, Mihaela KOLETNIK, 2013: Strokovni narečni jezikovni slovar na primeru koroške in panonske leksike s tematskega polja »vrt in sadovnjak«. Slovenski jezik v stiku podonavskega in alpskega prostora. Ur. Marko Jesenšek. Maribor: Mednarodna založba Oddelka za slovanske jezike in književnosti. (Zora, 93). 129-198.

Harald BURGER, Annelies BUHOFER, Ambros SIALM (ur.), 1982: Handbuch der Phraseologie. Berlin/New York: de Gruyter. 
Harald BURGER, 1998: Phraseologie. Eine Einführung am Beispiel des Deutschen. Berlin: Schmidt.

Christoph CHLOSTA, Peter GRZYBEK, Undine ROOS, 1994: Wer kennt denn heute noch den Simrock? Ergebnisse einer empirischen Untersuchung zur Bekanntheit deutscher Sprichwörter in traditionellen Sammlungen. Sprachbilder zwischen Theorie und Praxis. Ur. Christoph Chlosta, Peter Grzybek, Elisabeth Piirainen. Bochum: Brockmeyer. 31-60.

Peter ĎURČO, 1994: Probleme der allgemeinen und kontrastiven Phraseologie. Heidelberg: Julius Groos.

Peter ĎURČO, 2003: Unterschiede in der (Un)kenntnis von Sprichwörtern in verschiedenen Lebensaltern. Spracherwerb und Lebensalter. Ur. Annelies Häcki Buhofer. Tübingen/Basel: Francke. 293-304.

Peter ĎURČO/Matej METERC, 2013: Empirične paremiološke raziskave tipov ekvivalentnosti in suprasemantičnih razlik v slovenščini in slovaščini. Slavia Centralis VI/2, $20-36$.

Natalia FILATKINA, 2005: Phraseologie des Lëtzebuergeschen. Empirische Untersuchungen zu strukturellen, semantisch-pragmatischen und bildlichen Aspekten. Heidelberg: Universitätsverlag Winter.

Czaba FÖLDES, 1992: Zu den österreichischen Besonderheiten der deutschen Phraseologie. Deutsche Phraseologie in Sprachsystem und Sprachverwendung. Wien: Edition Praesens, 9-24.

Peter GRZYBEK, Rudi SCHLATTE, 2002: Zur Satzlänge deutscher Sprichwörter. Ein Neuansatz. Phraseologie in Raum und Zeit. Akten der 10. Tagung des Westfälischen Arbeitkreises Phraseologie/Parömiologie (Münster 2001). Ur. Elisabeth Piirainen, Ilpo Tapani Piirainen. Essen: Schneider. 287-305.

Peter GRZYBEK, 1991: Sinkendes Kulturgut? Eine empirische Pilotstudie zur Bekanntheit deutscher Sprichwörter. Wirkendes Wort 2, 239-264.

Peter GRZYBEK, 2008: Fundamentals of Slovenian Paremiology. Traditiones 37/1, $23-46$.

Peter GRZYBEK, 2012: Facetten des parömiologisches Rubik-Würfels. Kenntnis $\equiv$ Bekanntheit $[\leftrightarrow$ Verwendung $\approx$ Frequenz]?!? Sprichwörter multilingual. Ur. Kathrin Steyer. Tübingen: Narr. 99-138.

Annelies HÄCKI BUHOFER, Harald BURGER, 1994: Phraseologismen im Urteil von Sprecherinnen und Sprechern. EUROPHRAS 92. Tendenzen der Phraseologieforschung Ur. Barbara SANDIG. Bochum: Brockmeyer. 1-33.

Erla HALLSTEINSDÓTTIR, Monika ŠAJÁNKOVÁ, Uwe QUASTHOFF, 2006: Phraseologisches Optimum für Deutsch als Fremdsprache. Ein Vorschlag auf der Basis von Frequenz- und Geläufigkeitsuntersuchungen. Linguistik online 27, 117-136, http:// linguistik-online.de/27_06/hallsteinsdottir_et_al.html (27. 12. 2013).

Britta JUSKA-BACHER, 2009: Empirisch-kontrastive Phraseologie: am Beispiel der Bekanntheit der Niederländischen Sprichwörter im Niederländischen, Deutschen und Schwedischen. Baltmannsweiler: Schneider-Verl. Hohengehren. 
Britta JUSKA-BACHER, 2012: Empirische Methoden in der kontrastiven Sprichwörterforschung: Möglichkeiten der Informantenbefragung. Sprichwörter multilingual. Ur. Kathrin Steyer. Tübingen: Narr. 139-164.

Brigita KACJAN, Saša JAZBEC, 2012. Phraseme und Sprichwörter in offiziellen Dokumenten des slowenischen Bildungssystems. Vestnik za tuje jezike 4/1-2, 83-101.

Alja LIPAVIC OŠTIR, 2013: Poznavanje in raba slovenskih pregovorov: Študija iz vzhodnega dela slovenskega jezikovnega prostora. Več glav več ve: Frazeologija in paremiologija v slovarju in vsakdanji rabi. Ur. Vida Jesenšek, Saša Babič. 124-138.

Alja LIPAVIC OŠTIR, Simona ŠTAVBAR, 2013: Kenntnis und Gebrauch von Sprichwörtern bei zwei Gruppen österreichischer Jugendlicher. Linguistik online 59/2, http://www. linguistik-online.de/59_13/lipavic-ostirStavbar_a.html (27. 12. 2003).

Katrin LÜTHI, Hans-Peter NAUMANN, 2002: Nordic language history and phraseology/idiomatics. The Nordic Languages. Ur. Oskar BANDLE idr. Berlin/New York: Walter de Gruyter. 241-247.

Neal R. NORRICK, 2007: Proverbs as set phrases. Phraseologie. Phraseology. Ein internationales Handbuch der zeitgenössischen Forschung. Ur. Harald Burger idr. Berlin/ New York: de Gruyter. 381-393.

Marija MAKAROVIČ, 1975. Pregovori - življenjske resnice. Ljubljana: Kmečki glas.

Elisabeth PIIRAINEN, 2006: Phraseologie in arealen Bezügen: ein Problemaufriss. Linguistik online 27, 2/06, 195-218, www.linguistik-online.de/27_06/piirainen.pdf (27. 12. 2013).

Elisabeth PIIRAINEN, 2008: Phraseology in a European framework. A cross-linguistic and cross-cultural research project on widespread idioms. Phraseology. An interdisciplinary perspective. Ur. Sylviane Granger, Fanny Meunier. Amsterdam/Philadelphia: John Benjamins. 243-258.

Rolf PORST, 1996: Fragebogen: Ein Arbeitsbuch. Wiesbaden: VS.

\section{ENTRENCHMENT OF PROVERBS IN THE INDIVIDUAL LEXICONS OF NATIVE SPEAKERS OF SLOVENE}

The article highlights the results of a survey on the knowledge and the use of Slovene proverbs conducted among a group of Slovenian informants of various ages. It was assessed that proverbs are quite well entrenched in the individual passive lexicons of the majority of informants (an average of 83\%), who have expressed a significant level of proverb knowledge, while using them to a significantly lesser degree at the same time. An average of $24 \%$ of the informants surveyed stated that they frequently use proverbs verbally and an average of $12.4 \%$ stated that they frequently use proverbs when writing. The answers of informants aged 25 or less significantly deviate from other groups regarding the written use of proverbs. The results have also shown the verbal use of proverbs among informants aged 25 or less to be below the average share. A linear increase in the level of proverb knowledge was ascertained with regard to the level of education (from lower to higher) of the informants $(72.1 \%-82.4 \%-88.5 \%)$. Significant 
differences with regard to the factor of education were also observed in proverb use. However, discrepancies between the answers did not exceed the $12 \%$ margin. The survey has not indicated any major differences regarding the levels of proverb knowledge and proverb use respectively between informants from the metropolitan area (Maribor) and informants from the rural part of Slovenia. A similar incidence was observed regarding the factor of gender, where no significant differences were detected in the levels of proverb knowledge or frequency of proverb use between both groups. On the other hand, the survey revealed certain differences between the individual dialect groups. It will be possible to explain certain discrepancies only after additional studies, which would, by all means, raise new questions and establish additional directions for further research endeavours. 